\title{
均質化法による吸音材微視構造の寸法最適化
}

山本 崇史 ${ }^{* 1}$, 桂 大詞 ${ }^{* 2}$, 久保田 寛 ${ }^{* 2}$

\section{Sizing optimization of microstructure of sound-absorbing poroelastic material by homogenization method}

\author{
Takashi YAMAMOTO*1 $^{*}$, Daiji KATSURA ${ }^{* 2}$ and Hiroshi KUBOTA*2 \\ ${ }^{* 1}$ Department of Mechanical Engineering, Kogakuin University \\ 2665-1 Nakano-machi, Hachioji-shi, Tokyo 192-0015, Japan \\ ${ }^{* 2}$ Mazda Motor Corporation \\ 3-1 Shinchi, Fuchu-cho, Aki-gun, Hiroshima 730-8670, Japan
}

Received: 12 March 2020; Revised: 5 July 2020; Accepted: 24 August 2020

\begin{abstract}
Acoustic properties of sound-absorbing poroelastic media such as sound absorption coefficient are affected by microscopic structures. However, the design method for microscopic structures of sound-absorbing poroelastic media has not been established and the trial and error approach based on prototypes is required. In this study, a parametric optimization method to design microscopic structures of sound-absorbing poroelastic media is proposed. First, various models of microscopic structure of sound-absorbing material are generated by some sets of microscopic parameters and homogenized macroscopic properties, such as air flow resistivity and equivalent density and bulk modulus, are calculated by the homogenization method. Then, Biot's parameters are identified for each microscopic structure of sound-absorbing poroelastic material by using non-linear least square method, and the functions that link between Biot's parameters and the microscopic parameters, such as fiber diameter and pore radius, are derived. Finally, the microscopic parameters of poroelastic materials are optimized by using genetic algorithm (GA) to maximize sound absorption coefficient at prescribed target frequencies. In the verification of the proposed design method, the microscopic structures of fibrous porous material and foamed poroelastic material are optimized.
\end{abstract}

Keywords : Sound absorption coefficient, Poroelastic material, Homogenization, Multi scale, Optimization, Genetic algorithm

\section{1. 緒言}

自動車などの輸送機器や建物など室内における静肃性の向上は，快適性を高める重要な要素であり，その代表 的な方策の一つとして, 多孔質吸音材が多用されている. 多孔質吸音材の音響性能を示寸代表的な特性は吸音率 であり，吸音率は多孔質吸音材の微視構造に依存することが知られている。したがって，吸音率の目標値を満たす よう多孔質吸音材を設計するためには，多孔質吸音材の微視構造モデルが必要となる.

多孔質吸音材は, 基材となる固体相と, 数 $\mu \mathrm{m}$ から数百 $\mu \mathrm{m}$ の径の流路からなる流体相が混在した微視構造と なっている。これまで適用されてきた吸音材のモデルの一つに, Delany と Bazley (Delany and Bazley, 1970)によ る経験則に基づいたモデルがある. しかし，このモデルは，マクロパラメータである空気流れ抵抗で表現されて おり，微視構造を扱うことはできない。また，流体相しか考慮されておらず，流体相の体積分率が 100\%に近い繊

No.20-00073 [DOI:10.1299/transjsme.20-00073], J-STAGE Advance Publication date : 1 September, 2020

*1 正員, 工学院大学 工学部 機械工学科（产 192-0015 東京都八王子市中野町 2665-1）

*2 マツダ (株) 技術研究所 (厂730-8670 広島県安芸郡府中町新地 3-1)

E-mail of corresponding author: takashi_yamamoto@cc.kogakuin.ac.jp 
維系の吸音材に適用は限定される。近年広く適用されている Biot (Biot, 1956a,b), Allard (Allard and Atalla, 2009), Atalla ら (Atalla et al., 1998) によるモデル (Biot’s model) は，固体相と流体相の両方の特性を考慮しており，弾性 定数や空気流れ抵抗など 8 つパラメータ（Biot パラメータ）で表現されている. しかし，Biotパラメータはマ クロスケールで定義されており，多孔質吸音材の微視構造と直接関係付けることはできない. ただ，Biotパラメー タの值が得られていれば, 吸音率や音響透過損失などの音響性能を比較的少ない計算コストで求めることができ るという利点がある。

一方，多孔質体の微視構造からマクロスケールにおける特性や支配方程式を導出することを目的とした研究が これまでにいくつか報告されている (Auriault et al., 1985; Levy, 1979; Burridge and Keller, 1981; Boutin et al., 1998). 多くの研究は多孔質吸音材における物理現象の一部を扱ったものになっており，そのまま多孔質吸音材に適用する ことはできない，著者の一人は，従来の均質化法を多孔質吸音材に適用できるよう拡張しており (Yamamoto et al., 2011), 多孔質吸音材の微視構造モデルからマクロ特性を求め, そのマクロ特性から吸音率を直接求めることがで きる. 本手法により, 微視構造を直接設計することが可能となるものの, 計算負荷が大きく, 多様な微視構造を検 討することは容易ではない.

そこで，本研究では，均質化法により求めたマクロ特性から Biotパラメータを同定し，Biotパラメータと空孔 径, 繊維径や䋊維間距離などの微視構造を特徵づける寸法パラメータと関連付ける手法を提案する. これにより, 微視構造の寸法パラメータに対する吸音率を効率よく求めることができる。また，本手法を用いて微視構造パラ メータの最適設計を行う手法を提案する.

以下， 2 章では本研究で提案する多孔質吸音材の微視構造の寸法最適設計法の概略を説明し，3 章では提案手法 で用いる多孔質吸音材の均質化法について概説する。また，4章では均質化法による計算から得られたマクロ特性 を用いて Biot パラメータを同定する方法について述べる. 5 章で本提案手法を緎維系吸音材に, 6 章では発泡系吸 音材に適用する．最後に本研究のまとめと今後の課題について述べる.

\section{2. 均質化法による吸音材微視構造の最適設計法}

多孔質吸音材の吸音率 $\alpha$ や音響透過損失 $S T L$ などの音響的性能を予測する手法として，現在，図 1 に示すよ うな 2 つ方法がある.一つは, 図 1 の上部に黒矢印線で示しているように, Biotパラメータを実験的に同定し,

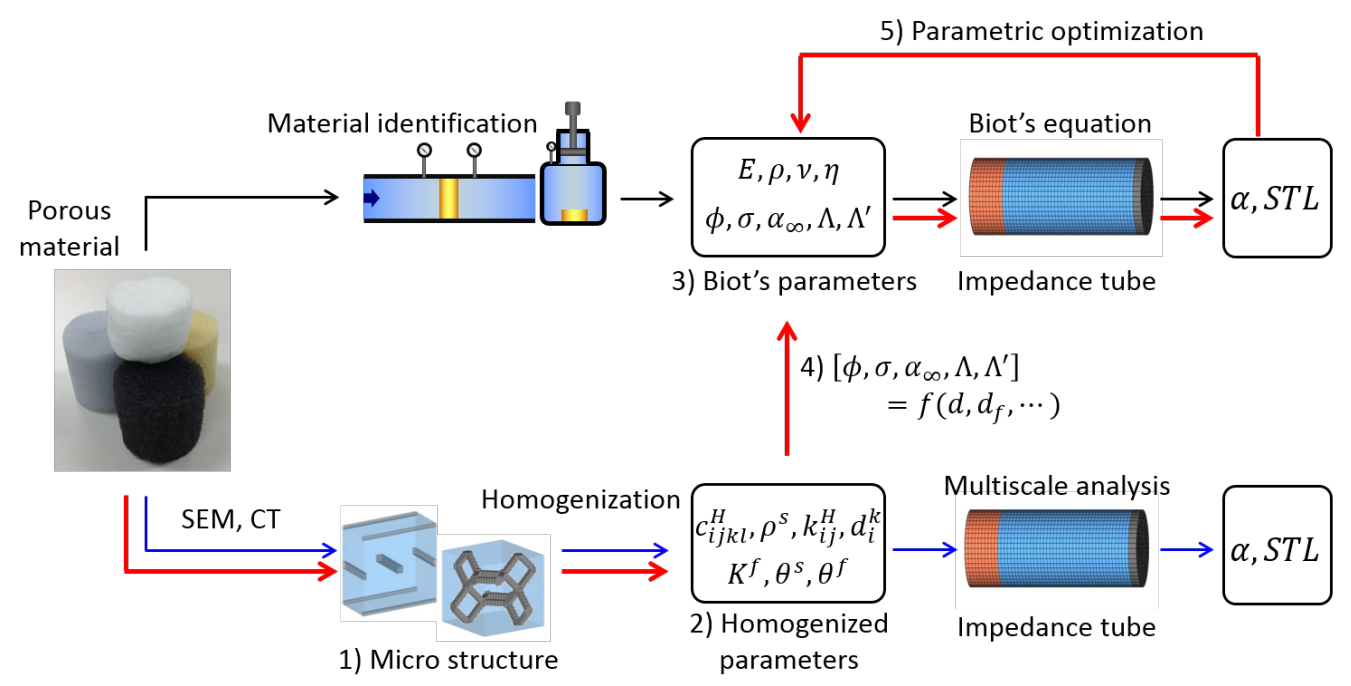

Fig. 1 Proposed process to design optimal microstructure of sound-absorbing poroelastic materials (in red line). 1) Microscopic models are generated for selected microscopic parameters, such as fiber diameter and pore size. 2) Homogenized properties are calculated by using Homogenization method. 3) Biot parameters are identified by using nonlinear least square method. 4) Microscopic parameters are linked with Biot parameters. 5) Microscopic parameters are optimized to maximize sound absorption coefficient by genetic alogrithm. 
Biot のモデルを用いる方法である. もう一つは, 図 1 の下部に青矢印線で示しているように, SEM や $\mu \mathrm{X}$ 線 CT などから得られた情報をもとに微視構造モデルを構築し, 均質化法を用いる方法である. 前者の方法では, 微視 構造を扱うことはできないが，Biotパラメータの值が得られれば，吸音率や音響透過損失などの音響性能を比較 的少ない計算コストで効率よく求めることができる. 後者の方法では, 微視構造を直接扱うことができるが, 均 質化法によりマクロ特性を算出する計算の負荷が大きく，多くの微視構造を検討することは容易ではない.

そこで, 本研究では図 1 の赤矢印線で示すように, 微視構造を取り扱うことのできる均質化法と, 効率よく吸音 率などの音響的性能を算出することのできるBiot のモデルを併用し, 多孔質吸音材の微視構造をパラメトリック に最適化するハイブリッド手法を提案する. すなわち, 多孔質吸音材の微視構造に対して繊維径や空孔径などを パラメータにした微視構造モデルを複数作成し, それらに均質化法を用いて等価密度などのマクロ特性を算出す る. 次に, Biotのモデルにおいて, 均質化法の計算により得られたマクロ特性と一致するようにBiotパラメータ を同定する. そして, 微視構造パラメータとBiotパラメータを関連付ける関数を導出する. この関数を用いるこ とで, 微視構造のパラメータを変更した場合でも, 吸音率などの音響的性能を容易に算出することができる.さ らに, 遺伝的アルゴリズムを適用し, 指定周波数で吸音率が最大となる微視構造のパラメータを求める.

\section{3. 多孔質吸音材の均質化}

多孔質吸音材に適用できるよう拡張した均質化法について概略を説明する。詳細は文献 (Yamamoto et al., 2011) を参照されたい。

図 2 に示すように周期的な微視構造を有する多孔質吸音材を考える. ミクロスケールにおける支配方程式につ いて, まず, 固体相は線形弾性体の平衡式・構成式・変位-ひずみ関係式とし, 流体相の流れ場は微小変位を仮定 し線形化した Navier-Stokes の方程式とする. また, 温度場は熱力学の第一法則にしたがうものとし, 固体相の比 熱が流体相の比熱に比して十分大きく平衡状態での温度を保持すると仮定し, 流体相のみ温度変動するものと考 える. 質量保存則および状態方程式も支配方程式として考慮し, また, 固体相と流体相の境界において速度, 垂

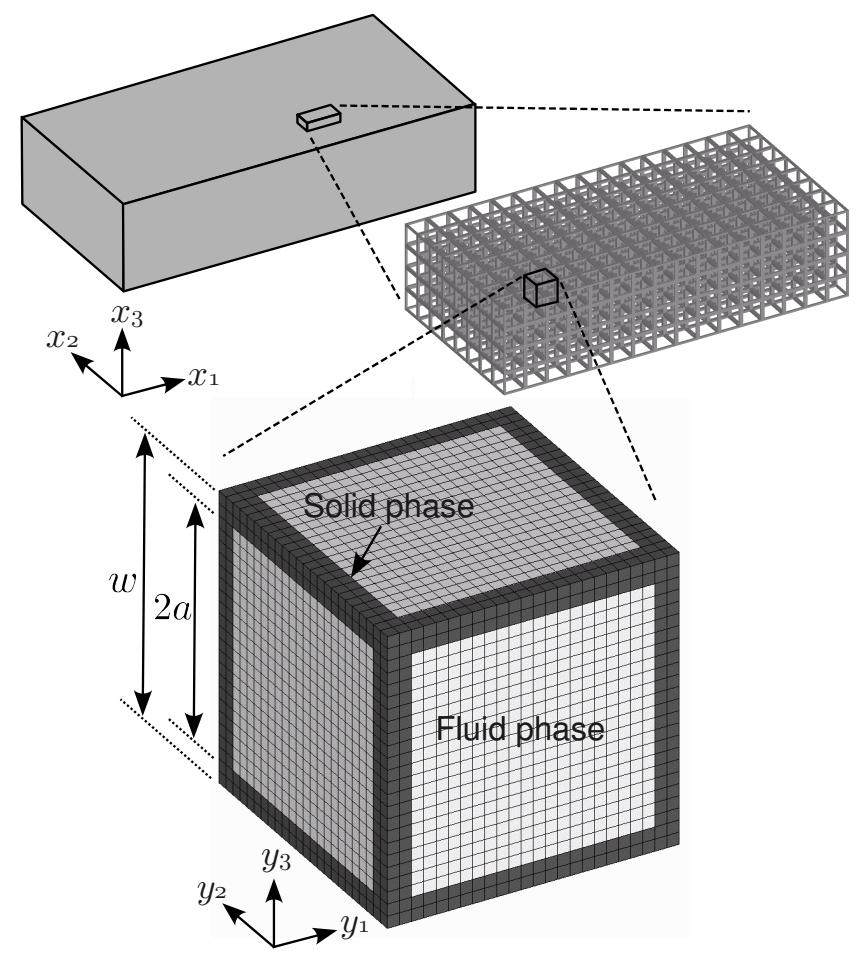

Fig. 2 Schematic view of homogenization method for sound-absorbing poroelastic material. Poroelastic material is assumed to be composed by periodically-aligned microscopic unit cell that is consisted by solid and fluid phases. Solid phase is made from isotropic elastic material, and fluid phase is made from compressive viscous fluid. 
直応力および温度の連続条件を課す，漸近展開をした解を仮定し，ミクロスケールにおける支配方程式に代入す ると，ミクロスケールにおける境界值問題を得ることができる．これらを解いて得られた解を体積平均すること でマクロスケールにおける均質化特性を得ることができる. また, ミクロスケールにおける支配方程式を平均化 することで，マクロスケールにおける固体相および流体相の支配方程式をそれぞれ導出することができる．これ を解くことで吸音率などの音響的性能を求めることができる.

\section{$3 \cdot 1$ 多孔質吸音材のミクロスケールにおける基礎支配方程式}

多孔質吸音材のミクロスケールにおける支配方程式について, 固体相は等方性の線形弾性体, 流体相は圧縮性 の粘性係数 $\mu^{f}$ の粘性流体で構成されているものとする. 固体相の支配方程式は, 固体相の変位を $u_{i}^{s}$, 質量密度を $\rho^{s}$, 弾性テンソルを $c_{i j k l}^{s}$, 応力を $\sigma_{i j}^{s}$, ひずみを $\varepsilon_{k l}^{s}$ とすると, 以下の式で表される.

$$
-\rho^{s} \omega^{2} u_{i}^{s}=\frac{\partial \sigma_{i j}^{s}}{\partial x_{j}}, \sigma_{i j}^{s}=c_{i j k l}^{s} \varepsilon_{k l}^{s}, \quad \varepsilon_{k l}^{s}=\frac{1}{2}\left(\frac{\partial u_{k}^{s}}{\partial x_{l}}+\frac{\partial u_{l}^{s}}{\partial x_{k}}\right)
$$

ここで, $\omega$ は角振動数である. 流体相の速度を $v_{i}^{f}$, 質量密度を $\rho^{f}$, 応力を $\sigma_{i j}^{f}$, ひずみを $\varepsilon_{i j}^{f}$, 音圧を $p^{f} と し$, 速 度振幅が微小で速度の二乗の項が無視できるとすると, 流体相の流れ場に関する支配方程式は, 以下に示すよう に，線形化された Navier-Stokes の方程式で表される.

$$
\rho^{f} j \omega v_{i}^{f}=\frac{\partial \sigma_{i j}^{f}}{\partial x_{j}}, \quad \sigma_{i j}^{f}=-p^{f} \delta_{i j}+2 \mu^{f} \dot{\varepsilon}_{i j}^{f}-\frac{2}{3} \mu^{f} \delta_{i j} \dot{\varepsilon}_{k k}^{f}, \quad \dot{\varepsilon}_{i j}^{f}=\frac{1}{2}\left(\frac{\partial v_{i}^{f}}{\partial x_{j}}+\frac{\partial v_{j}^{f}}{\partial x_{i}}\right)
$$

ここで, $j$ は虚数単位, $\delta_{i j}$ は Kronecker のデルタである. 固体相の比熱は流体相の比熱に比して十分大きく, 平 衡状態での温度 $T^{f}$ を維持すると仮定すると, 温度場は流体相のみを考慮すればよく, 温度变動を $\tau^{f}$, 熱流速を $q_{i}^{f}$ とすると, 支配方程式は熱力学の第一法則より次式で表すことができる.

$$
-\frac{\partial q_{i}^{f}}{\partial x_{i}}=j \omega \rho^{f} C_{v}^{f} \tau^{f}+\left(j \omega \rho^{f} R \tau^{f}-j \omega p^{f}\right), q_{i}^{f}=-\kappa_{i j}^{f} \frac{\partial \tau^{f}}{\partial x_{j}}
$$

ここで, $C_{v}^{f}$ は定積比熱, $R$ は気体定数, $\kappa_{i j}^{f}$ は熱伝導率テンソルである. また, 流体相に関する質量保存則および 状態方程式はそれぞれ次式で表すことができる.

$$
\rho^{f} \frac{\partial v_{i}^{f}}{\partial x_{i}}+j \omega \delta^{f}=0, \frac{p^{f}}{P^{f}}=\frac{\delta^{f}}{\rho^{f}}+\frac{\tau^{f}}{T^{f}}
$$

ここで, $\delta^{f}$ は質量密度の変動を表す, 固体相と流体相の境界 $\Gamma^{s f}$ における境界条件は, 速度, 境界垂直方向の応 力，および温度の連続性から以下のように書くことができる。

$$
j \omega u_{i}^{s}=v_{i}^{f}, \quad \sigma_{i j}^{s} n_{j}^{s}+\sigma_{i j}^{f} n_{j}^{f}=0, \tau^{f}=0
$$

ここで， $n_{i}^{s}, n_{i}^{f}$ はそれぞれ， $\Gamma^{s f}$ に立てた固体相，流体相の領域外向きの単位法線ベクトルである.

\section{2 漸近展開}

微視構造は周期的であると仮定し, その単位領域（ユニットセル）を $Y$, ユニットセルの大きさを $l$ とする. マク ロスケールの代表長さ $L$ は多孔質体における波長とし, ミクロスケールとマクロスケールの代表長さの比を $\varepsilon=l / L$ とする. また，マクロスケールにおける空間変数を $\boldsymbol{x}$ ，ミクロスケールにおける空間変数を $\boldsymbol{y}=\boldsymbol{x} / \varepsilon(\varepsilon \ll 1)$ とす る. Gilbert ら (Gilbert and Mikelić, 2000) や Clopeau ら (Clopeau et al., 2001) が two-scale 収束論を適用し数学的に 明らかにしているように, 多孔質体の問題においても漸近展開形の解が成り立つ. ここでは, 状態量 $u_{i}^{s}, v_{i}^{f}, p^{f}$, $\tau^{f}, \delta^{f}$ に対して, 次式のような漸近展開形の解 (Sanchez-Palencia, 1980) を仮定する.

$$
\begin{aligned}
u_{i}^{s} & =u_{i}^{s(0)}(\boldsymbol{x}, \boldsymbol{y})+\varepsilon u_{i}^{s(1)}(\boldsymbol{x}, \boldsymbol{y})+\varepsilon^{2} u_{i}^{s(2)}(\boldsymbol{x}, \boldsymbol{y})+\cdots \\
v_{i}^{f} & =v_{i}^{f(0)}(\boldsymbol{x}, \boldsymbol{y})+\varepsilon v_{i}^{f(1)}(\boldsymbol{x}, \boldsymbol{y})+\varepsilon^{2} v_{i}^{f(2)}(\boldsymbol{x}, \boldsymbol{y})+\cdots \\
p^{f} & =p^{f(0)}(\boldsymbol{x}, \boldsymbol{y})+\varepsilon p^{f(1)}(\boldsymbol{x}, \boldsymbol{y})+\varepsilon^{2} p^{f(2)}(\boldsymbol{x}, \boldsymbol{y})+\cdots \\
\tau^{f} & =\tau^{f(0)}(\boldsymbol{x}, \boldsymbol{y})+\varepsilon \tau^{f(1)}(\boldsymbol{x}, \boldsymbol{y})+\varepsilon^{2} \tau^{f(2)}(\boldsymbol{x}, \boldsymbol{y})+\cdots \\
\delta^{f} & =\delta^{f(0)}(\boldsymbol{x}, \boldsymbol{y})+\varepsilon \delta^{f(1)}(\boldsymbol{x}, \boldsymbol{y})+\varepsilon^{2} \delta^{f(2)}(\boldsymbol{x}, \boldsymbol{y})+\cdots
\end{aligned}
$$


ここで, 右辺における全ての項は $\boldsymbol{y}$ について周期的（ $Y$-periodic $)$ である.これら漸近展開形の解を支配方程式 (1)〜(5)に代入し，\&のオーダーで整理する.

\section{$3 \cdot 3$ 境界値問題}

固体相の $\varepsilon^{-1}$ のオーダーの関係式に Galerkin 法を適用すると, 固体相の変位に関する $Y$-periodic な特性関数 $\chi_{i}^{k l}(\boldsymbol{y})$ について, $\delta u_{i}^{s}$ を重み関数とする以下の境界值問題を得ることができる.

$$
\int_{Y}\left(c_{i j k l}^{s}-c_{i j p q}^{s} \frac{\partial \chi_{p}^{k l}(\boldsymbol{y})}{\partial y_{q}}\right) \frac{\partial \delta u_{i}^{s}}{\partial y_{j}} d Y=0
$$

剛体変位を除くため $\int_{Y} \chi_{i}^{k l}(\boldsymbol{y}) d Y=0$ の条件のもと上式を解くと特性関数 $\chi_{i}^{k l}(\boldsymbol{y})$ を求めることができる.

$\varepsilon^{0}$ のオーダーにおける流体相の固体相に対する相対速度 $w_{i}^{f(0)}=v_{i}^{f(0)}-j \omega u_{i}^{s(0)}$ を考え, $v_{i}^{f(0)}$ を $w^{f(0)}+j \omega u_{i}^{s(0)}$ で置き換える. $\varepsilon^{-1}$ のオーダーの関係式より流体相の流れ場に関して $, \delta w_{i}^{f}, \delta p^{f}$ を重み関数とする次のミクロス ケールにおける境界値問題を得ることができる.

$$
\begin{aligned}
& \int_{Y} \rho^{f} j \omega \xi_{i}^{k}(\boldsymbol{y}) \delta w_{i}^{f} d Y+\int_{Y} \mu^{f} \frac{\partial \xi_{i}^{k}(\boldsymbol{y})}{\partial y_{j}} \frac{\partial \delta w_{i}^{f}}{\partial y_{j}} d Y+\int_{Y} \frac{1}{3} \mu^{f} \frac{\partial \xi_{i}^{k}(\boldsymbol{y})}{\partial y_{i}} \frac{\partial \delta w_{i}^{f}}{\partial y_{i}} d Y \\
&-\int_{Y} \frac{\partial \xi_{i}^{k}(\boldsymbol{y})}{\partial y_{i}} \delta p^{f} d Y-\int_{Y} \frac{\partial \delta w_{i}^{f}}{\partial y_{i}} \pi^{k}(\boldsymbol{y}) d Y=\int_{Y} \delta \xi_{k}^{k}(\boldsymbol{y}) d Y
\end{aligned}
$$

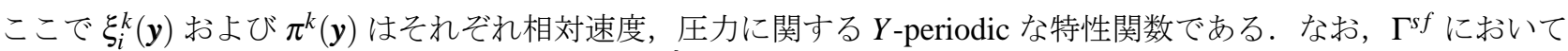
$\xi_{i}^{k}(\boldsymbol{y})=0$ である. 一定圧力の成分を除くため $\int_{Y} \pi^{k}(\boldsymbol{y}) d Y=0$ の条件を付加して解くことで, $\xi_{i}^{k}(\boldsymbol{y})$ および $\pi^{k}(\boldsymbol{y})$ を求めることができる.

$\varepsilon^{0}$ のオーダーにおける流体相の温度 $\tau^{f(0)}$ についての関係式より, $\delta \tau^{f}$ を重み関数とする次の境界值問題を得る ことができる.

$$
\int_{Y} \frac{1}{j \omega \rho^{f} C_{p}^{f}} \kappa_{i j}^{f} \frac{\partial \zeta(\boldsymbol{y})}{\partial y_{j}} \frac{\partial \delta \tau^{f}}{\partial y_{i}} d Y+\int_{Y} \zeta(\boldsymbol{y}) \delta \tau^{f} d Y=\int_{Y} \delta \tau^{f} d Y
$$

ここで $\zeta(\boldsymbol{y})$ は温度に関する $Y$-periodic な特性関数であり， $\Gamma^{s f}$ において温度変動がゼロの条件 $\zeta(\boldsymbol{y})=0$ をみたす.

\section{4 均質化法により得られるマクロ特性}

境界值問題を解き得られた特性関数 $\chi_{i}^{k l}(\boldsymbol{y})$ をユニットセル $Y$ において体積平均をとることで, 固体相の均質弾 性テンソル $c_{i j k l}^{H}$ は，次式により求めることができる (Terada et al., 1998).

$$
c_{i j k l}^{H}=\frac{1}{|Y|} \int_{Y}\left[c_{i j k l}^{s}-c_{i j p q}^{s} \frac{\partial \chi_{p}^{k l}(\boldsymbol{y})}{\partial y_{q}}\right] d Y
$$

ここで, $|Y|$ は多孔質体のユニットセル $Y$ の体積である.

また, ユニットセル中の流体相 $Y^{f}$ において $\xi_{i}^{k}(\boldsymbol{y})$ の体積平均をとると, 流体相の等価密度 $\rho_{k i}^{f c}$ を次式で求める ことができる.

$$
\rho_{k i}^{f c}=\frac{1}{j \omega}\left\langle\xi_{i}^{k}(\boldsymbol{y})\right\rangle_{Y^{f}}^{-1}
$$

ただし, $\left|Y^{f}\right|$ をユニットセル中の流体相 $Y^{f}$ の体積, 〈 $\rangle_{Y^{f}}$ は $Y^{f}$ における体積平均である.

流体相の等価体積弾性率 $K^{f}$ はュニットセル中の流体相 $Y^{f}$ において $\zeta(y)$ の体積平均をとることで以下のよう に求めることができる.

$$
K^{f}=\frac{\gamma^{f} P^{f}}{\gamma^{f}-\left(\gamma^{f}-1\right)\langle\zeta(\boldsymbol{y})\rangle_{Y^{f}}}
$$




\section{5 マクロスケールの支配方程式}

得られたマクロ特性を用いて，マクロスケールにおける固体相および流体相の支配方程式をそれぞれ以下のよ うに導出することができる.

$$
\begin{aligned}
& \frac{\partial \hat{\sigma}_{i j}^{s(0)}}{\partial x_{j}}+\bar{\rho} \omega^{2} u_{i}^{s(0)}-\rho^{f} \omega^{2} d_{i}^{k} u_{k}^{s(0)}-j \omega d_{i}^{k} \frac{\partial \psi^{f(0)}}{\partial x_{k}}+j \omega \phi \frac{\partial \psi^{f(0)}}{\partial x_{i}}+j \omega k_{i j}^{H} \frac{\partial \psi^{f(0)}}{\partial x_{j}}=0 \\
& \frac{d_{i}^{k}}{\rho^{f}} \frac{\partial^{2} \psi^{f(0)}}{\partial x_{k} \partial x_{i}}+\omega^{2}\left(\theta^{f}+\frac{\phi}{K^{f}}\right) \psi^{f(0)}-j \omega d_{i}^{k} \frac{\partial u_{k}^{s(0)}}{\partial x_{i}}+j \omega \phi \frac{\partial u_{i}^{s(0)}}{\partial x_{i}}+j \omega \theta^{s, p q} \varepsilon_{p q}^{s(0)}=0
\end{aligned}
$$

ここで, $\psi^{f(0)}$ は $p^{f(0)}=-j \omega \psi^{f(0)}$ と定義されるポテンシャル関数, $\hat{\sigma}_{i j}^{s(0)}$ は流体相との連成を考慮しない場合の固 体相の応力, $\phi$ は空孔率, $\bar{\rho}$ は多孔質体の平均質量密度で $\bar{\rho}=(1-\phi) \rho^{s}+\phi \rho^{f}$ である. また, $k_{i j}^{H}, \theta^{s, p q}$ は固体相 に関する均質化マクロ特性, $\theta^{f}, d_{i}^{k}$ は流体相に関する均質化マクロ特性であり, 以下の式で表されるものである.

$$
\begin{aligned}
k_{i j}^{H} & =\frac{1}{|Y|} \int_{Y} c_{i j k l}^{s} \frac{\partial \eta_{k}(\boldsymbol{y})}{\partial y_{l}} d Y \\
\theta^{s, p q} & =\frac{1}{|Y|} \int_{Y} \frac{\partial \chi_{k}^{p q}(\boldsymbol{y})}{\partial y_{k}} d Y \\
\theta^{f} & =\frac{1}{|Y|} \int_{Y} \frac{\partial \eta_{k}(\boldsymbol{y})}{\partial y_{k}} d Y \\
d_{i}^{k} & =\frac{1}{|Y|} \int_{Y} \rho^{f} j \omega \xi_{i}^{k}(\boldsymbol{y}) d Y
\end{aligned}
$$

\section{Biot パラメータの同定}

Biot のモデルの平衡式や構成式については，文献 (Biot, 1956a,b; Allard and Atalla, 2009; Atalla et al., 1998) を参 照されたい. 固体相に関しては, Laméの定数 $\lambda, \mu$, 質量密度 $\rho$ の 3 つ, 流体相に関しては, 空孔率 $\phi$, トーチュ オシティ $\alpha_{\infty}$, 空気流れ抵抗 $\sigma$, 粘性特性長 $\Lambda$, 熱的特性長 $\Lambda^{\prime}$ の 5 つのパラメータが用いられている. いずれも マクロスケールで定義され，微視構造と直接関係付けられてはいない．ここでは，均質化法による計算から得ら れたマクロ特性より, Biot パラメータを同定する手法について述べる.

\section{$4 \cdot 1$ 弾性率，ポアソン比および質量密度}

Biot のモデルでは，一般的に固体相は等方性の線形弾性体として扱う。ここでは，均質化法による計算から得 られた均質化弾性テンソル $c_{i j k l}^{H}$ を用いて, 等方性線形弾性体の弾性テンソルの各成分との残差二乗和 $f$ が最小と なるヤング率 $E$ とポアソン比 $v$ を求める. Lamé の定数を $\lambda, \mu$ とすると, 残差二乗和 $f$ は以下のように書くこ とができる.

$$
\begin{aligned}
f=\left(\lambda+2 \mu-c_{1111}^{H}\right)^{2}+\left(\lambda+2 \mu-c_{2222}^{H}\right)^{2}+\left(\lambda+2 \mu-c_{3333}^{H}\right)^{2} & +\left(\lambda-c_{2233}^{H}\right)^{2}+\left(\lambda-c_{3311}^{H}\right)^{2}+\left(\lambda-c_{1122}^{H}\right)^{2} \\
& +\left(\mu-c_{2323}^{H}\right)^{2}+\left(\mu-c_{3131}^{H}\right)^{2}+\left(\mu-c_{1212}^{H}\right)^{2}
\end{aligned}
$$

$f$ の $\lambda, \mu$ に関する停留条件 $\frac{\partial f}{\partial \lambda}=\frac{\partial f}{\partial \mu}=0$ より, Lamé の定数 $\lambda, \mu$ は次式で求めることができる.

$$
\lambda=\frac{5}{18} C_{1}-\frac{1}{9} C_{2}, \mu=-\frac{1}{9} C_{1}+\frac{1}{9} C_{2}
$$

ただし，

$$
\begin{aligned}
& C_{1}=c_{1111}^{H}+c_{2222}^{H}+c_{3333}^{H}+c_{2233}^{H}+c_{3311}^{H}+c_{1122}^{H} \\
& C_{2}=2\left(c_{1111}^{H}+c_{2222}^{H}+c_{3333}^{H}\right)+c_{2323}^{H}+c_{3131}^{H}+c_{1212}^{H}
\end{aligned}
$$

である。これより, ヤング率 $E$ とポアソン比 $v$ は次式で求められる.

$$
E=\frac{(3 \lambda+2 \mu) \mu}{\lambda+\mu}, v=\frac{\lambda}{2(\lambda+\mu)}
$$

また, 質量密度 $\rho$ は, 均質化法の計算で求めた $\bar{\rho}$ に等しい。 


\section{$4 \cdot 2$ 空孔率}

空孔率 $\phi$ は, 多孔質体に占める流体相の体積分率であり, 微視構造の有限要素モデルから次式で容易に求める ことができる.

$$
\phi=\left|Y^{f}\right| /|Y|
$$

ここで， $\left|Y^{f}\right|$ はユニットセルの流体相の体積，|Y| はユニットセルの体積である.

\section{$4 \cdot 3$ 空気流れ抵抗}

空気流れ抵抗テンソル $\sigma_{i j}$ は流速 $v_{i}$ で空気を多孔質吸音材に流入させたときに， $x_{j}$ 方向に生じる単位厚さあた りの圧力損失であり，次式で定義される.

$$
\sigma_{i j} v_{i}=-\frac{\partial p}{\partial x_{j}}
$$

一方，流体相の均質化計算より平均流速 $\left\langle w_{i}^{(0)}\right\rangle_{Y^{f}}$ は以下で求められる.

$$
\left\langle w_{i}^{(0)}\right\rangle_{Y^{f}}=\left\langle\xi_{i}^{j}(\boldsymbol{y})\right\rangle_{Y^{f}}\left(-\frac{\partial p^{(0)}}{\partial x_{i}}\right)
$$

上の二式を比較すると空気流れ抵抗テンソル $\sigma_{i j}$ は以下で求めることができる.

$$
\sigma_{i j}=\left\langle\xi_{i}^{j}(\boldsymbol{y})\right\rangle_{Y f}^{-1}
$$

Biotパラメータとしては，垂直入射吸音率を算出する際の音波の入射方向に対応する空気流れ抵抗值を用いる.

\section{4 トーチュオシティと粘性特性長}

均質化法による計算から得られる流体相の等価密度と Biot のモデルにおける等価密度の残差二乗和が最小にな るよう，トーチュオシティ $\alpha_{\infty}$ と粘性特性長 $\Lambda$ の值を同定する. Biot のモデルにおける流体相の等価密度 $\rho^{f c}$ は, $\rho^{f}$ を空気の質量密度として次式で表される。

$$
\rho^{f c}=\rho^{f} \alpha_{\infty}+\frac{\sigma \phi}{j \omega} G, G=\left(1+\frac{4 j \omega v^{f}}{\Lambda^{2}} \frac{\rho^{f 2} \alpha_{\infty}^{2}}{\sigma^{2} \phi^{2}}\right)^{\frac{1}{2}}
$$

ただし， $v^{f}$ は動的粘性係数で, $v^{f}=\mu^{f} / \rho^{f}$ である.ここで, $\rho^{f}=1.2 \mathrm{~kg} / \mathrm{m}^{3}$ および $\mu^{f}=1.84 \times 10^{-5} \mathrm{Ns} / \mathrm{m}^{2}$ とし ている，上式は未知数 $\alpha_{\infty}, \Lambda$ について線形ではないため，非線形最小二乗法である Levenberg-Marquardt 法を適 用する. なお, Levenberg-Marquardt 法を, 上式のような複素関数に適用する場合, 複素残差 $r$ の絶対值の二乗 $r r^{*}$ の和を最小にするものとする. また, Levenberg-Marquardt 法は反復計算による方法で初期值を与える必要があり, 同定する未知数が 2 つ場合, 初期值により得られる解が異なる場合がある.ここでは, 等価密度の実部が $\omega \rightarrow 0$ のときに一定值に収束することを利用し，同定する未知数を 1 つにする．すなわち， $\omega \rightarrow 0$ のとき

$$
G \approx 1+\frac{2 j \omega v^{f}}{\Lambda^{2}} \frac{\rho^{f 2} \alpha_{\infty}^{2}}{\sigma^{2} \phi^{2}}
$$

より，

$$
\frac{\rho^{f c}}{\rho^{f}} \approx \alpha_{\infty}+\frac{\sigma \phi}{j \omega \rho^{f}}\left(1+\frac{2 j \omega v^{f}}{\Lambda^{2}} \frac{\rho_{0}^{f 2} \alpha_{\infty}^{2}}{\sigma^{2} \phi^{2}}\right)=\alpha_{\infty}+\frac{2 \mu^{f}}{\sigma \phi} \frac{\alpha_{\infty}^{2}}{\Lambda^{2}}+\frac{\sigma \phi}{j \omega \rho^{f}}
$$

となり，等価密度の実部は次式のように一定値 $c$ となることが分かる.

$$
\alpha_{\infty}+\frac{2 \mu^{f}}{\sigma \phi} \frac{\alpha_{\infty}^{2}}{\Lambda^{2}}=c
$$

これより，

$$
\Lambda^{2}=\frac{2 \mu^{f}}{\sigma \phi} \frac{\alpha_{\infty}^{2}}{c-\alpha_{\infty}}
$$


となる．元の式 (32) に代入すると

$$
\rho^{f c}=\rho^{f} \alpha_{\infty}+\frac{\sigma \phi}{j \omega} G, G=\left[1+\frac{2 j \omega \rho^{f}\left(c-\alpha_{\infty}\right)}{\sigma \phi}\right]^{\frac{1}{2}}
$$

となり，Levenberg-Marquardt 法で同定すべき未知数はトーチュオシティ $\alpha_{\infty}$ の 1 つとなる．なお，一定值 $c$ は均 質化法による計算から得られる。

\section{$4 \cdot 5$ 熱的特性長}

均質化法による計算から得られる等価体積弾性率とBiot のモデルにおける等価体積弾性率の残差二乗和が最小 になるよう，熱的特性長 $\Lambda^{\prime}$ の值を同定する. Biot のモデルにおける等価体積弹性率 $K^{f}$ は次式で表される.

$$
K^{f}=\frac{\gamma^{f} P^{f}}{\gamma^{f}-\left(\gamma^{f}-1\right)\left(1+\frac{8 v^{\prime} f}{j \omega \Lambda^{\prime 2}} G^{\prime}\right)^{-1}}, G^{\prime}=\left(1+\frac{j \omega \Lambda^{\prime 2}}{16 v^{\prime} f}\right)^{\frac{1}{2}}
$$

ここで, $v^{\prime} f$ は温度拡散率, $P^{f}$ は大気圧で, 定圧比熱を $C_{p}^{f}$ として $v^{\prime} f=\kappa^{f} /\left(\rho^{f} C_{p}^{f}\right)$ で定義される. なお, 比熱比 は $\gamma^{f}=1.4$ としている．等価体積弾性率も複素関数で表されることから Levenberg-Marquardt 法を適用する．この 場合，同定する未知数は熱的特性長 $\Lambda^{\prime}$ の 1 つである.

\section{5. 䋊維材料の微視構造最適化}

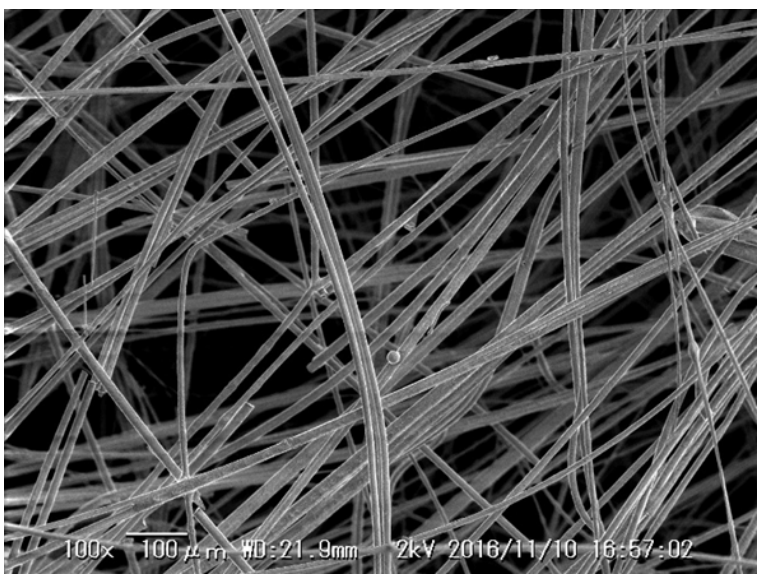

Fig. 3 Typical microscopic structure of fibrous poroelastic material obtained by scanning electron microscope (SEM). Straight fibers are stacked horizontally.

図 3 は代表的な繊維系吸音材を走査型電子顕微鏡により撮像したものである. 瀻維系吸音材は図に示すように, 繊維が平面的に積層して構成されている. 繊維の配向は平面内において特定の方向に偏ることはなく, 等方的と みなすことができる．また，繊維系吸音材のヤング率は空孔内空気の体積弹性率に比して小さいため，固体相の 吸音率への影響は無視できることが多い。 その場合, Biotのモデルにおいて固体相の弹性率をゼロとし，繊維の 質量による慣性項のみを考慮した Limp フレームモデルがよく用いられている.

本研究では, Limp フレームモデルを微視構造において表現したモデルを用いる. すなわち, 図 4(a) に示すよう に, 繊維の配向角は $0^{\circ}$ と $90^{\circ}$ を考慮し, 各緘維は接触することなく繊維間距離 $d_{f}$ の間隔で配置しているものと する．また，繊維の断面形状は，一般的に円形に近いが，ここでは 1 辺の長さが $d$ の正方形で近似する. 図 4(b) は，ユニットセルの構造を示しており，ここでは非接触直交ファイバーモデルと称する.

\section{$5 \cdot 1$ Biot パラメータと微視的パラメータの関係式}

繊維径 $d$ および䋊維間距離 $d_{f}$ を微視的パラメータとし, それらの值を変更して作成した多様なユニットセルモ デルについて，上述した均質化法を適用し，その結果から Biotパラメータを同定する．また，得られた Biot パ 


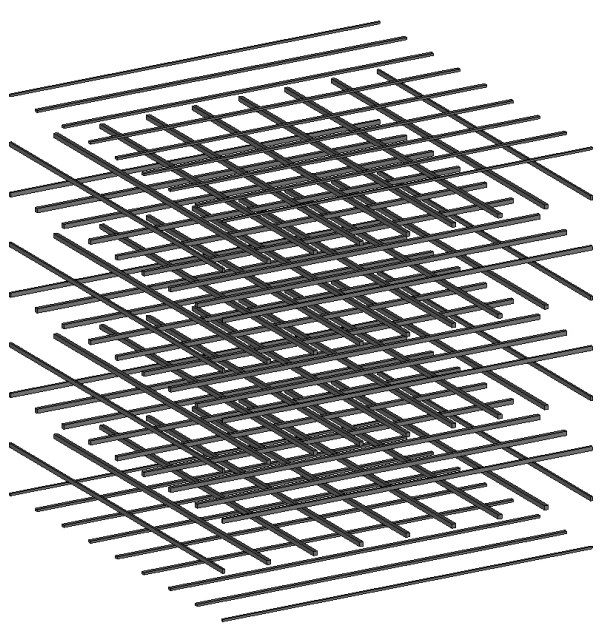

(a)

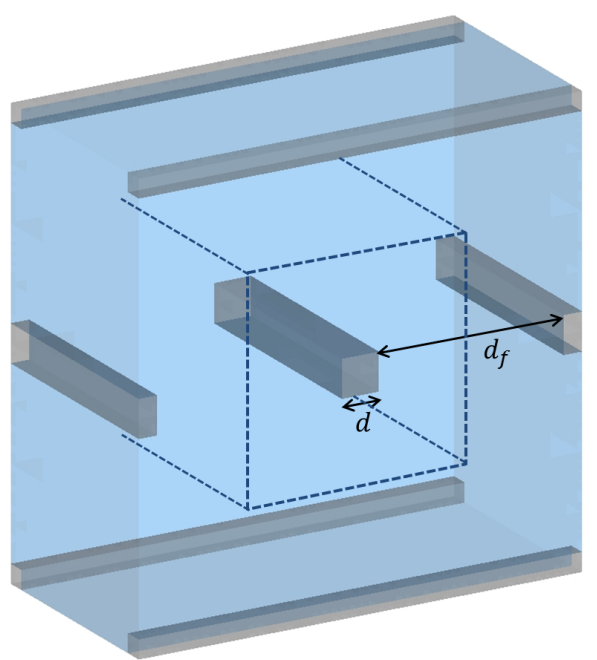

(b)

Fig. 4 (a) Micro structure model of fibrous poroelatic material. Straight fibers are orthogonally aligned. (b) Unit cell model of fibrous poroelatic material. Rectangular section is assumed due to the simplicity of model geometry. Fibers that have rectangular section of size $d \times d$ are aligned orthogonally with periodicity of $d_{f}$.

ラメータと微視的パラメータの関係式を導出する。実験的にも同様の手順をとることは可能であるが，実材料で は繊維径や繊維間距離を制御することは容易ではなく，また繊維径の分布やばらつきもある。均質化法の計算に おいて周期構造を仮定するという制約があるが，指定した微視的パラメータを有する微視構造を正確に表現した 上で数值実験を行うことができるという利点があると考える.

図 4 に示す微視構造の場合，空孔率 $\phi$ は $\phi=1-d^{2} /\left(d+d_{f}\right)^{2}$ と表すことができることから，空孔率 $\phi$ を繊維間 距離 $d_{f}$ と等価な微視的パラメータとする. ここでは, 繊維径 $d$ を $0.5 \mu \mathrm{m}, 1.0 \mu \mathrm{m}, 5.0 \mu \mathrm{m}, 10 \mu \mathrm{m}, 20 \mu \mathrm{m}, 30 \mu \mathrm{m}$, $40 \mu \mathrm{m}, 60 \mu \mathrm{m}, 80 \mu \mathrm{m}, 100 \mu \mathrm{m}$ の 10 種，空孔率 $\phi$ を 0.7500, 0.8264, 0.8889, 0.9375, 0.9722,0.9931の 5 種の組夕合 わせをとり，計 50 種類の微視構造について，均質化法による計算結果より Biot パラメータの值を同定した。表 1 に，例として 3 つケースについて求めた Biot パラメータの值を示す.

Table 1 Biot's parameters of some selective micro structures of fibrous poroelastic material. Porosity $\phi$ and air flow resistivity $\sigma$ are obtained directly from the results by the homogenization method. Tortuosity $\alpha_{\infty}$, viscous characteristic length $\Lambda$ and thermal characteristic length $\Lambda^{\prime}$ are identified by a nonlinear least square method using the equivalent density and bulk modulus obtained by the homogenization method.

\begin{tabular}{cccc}
\hline & $\begin{array}{c}d=5 \mu \mathrm{m} \\
d_{f}=25 \mu \mathrm{m}\end{array}$ & $\begin{array}{c}d=5 \mu \mathrm{m} \\
d_{f}=10 \mu \mathrm{m}\end{array}$ & $\begin{array}{c}d=10 \mu \mathrm{m} \\
d_{f}=50 \mu \mathrm{m}\end{array}$ \\
\hline \hline Porosity $\phi[-]$ & 0.9722 & 0.8889 & 0.9722 \\
\hline Air flow resistivity $\sigma\left[\mathrm{kNs} / \mathrm{m}^{4}\right]$ & 249.9 & 2255. & 62.46 \\
\hline Tortuosity $\alpha_{\infty}[-]$ & 1.013 & 1.095 & 1.013 \\
\hline Viscous characteristic length $\Lambda[\mu \mathrm{m}]$ & 31.91 & 9.392 & 63.82 \\
\hline Thermal characteristic length $\Lambda^{\prime}[\mu \mathrm{m}]$ & 34.75 & 11.75 & 69.72 \\
\hline
\end{tabular}

図 5 は, 表 1 の左端列にある䋊維径 $d$ が $5 \mu \mathrm{m}$, 繊維間距離 $d_{f}$ が $25 \mu \mathrm{m}$ の場合について, 均質化法の計算結果 より直接求めた等価密度・等価体積弾性率と，同定したトーチューシティ $\alpha_{\infty}$ と粘性特性長 $\Lambda$ ・熱的特性長 $\Lambda^{\prime}$ お 

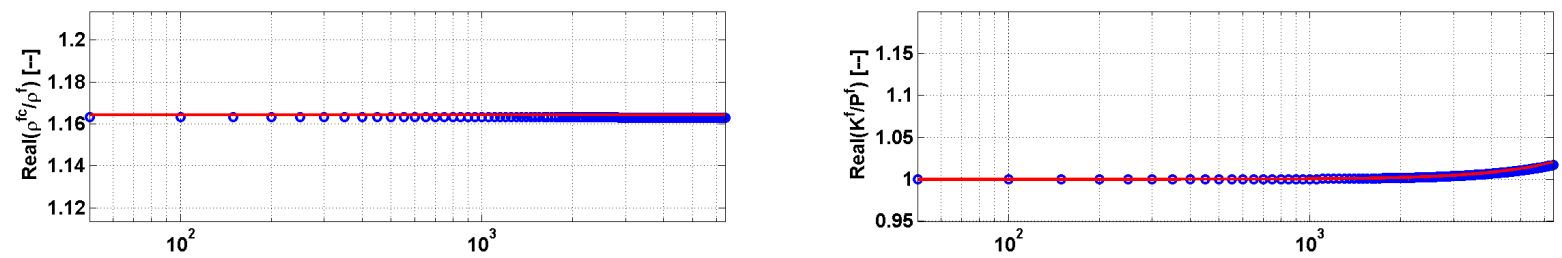

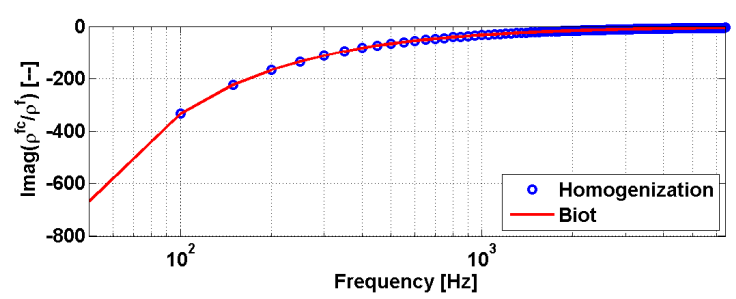

(a) Equivalent density

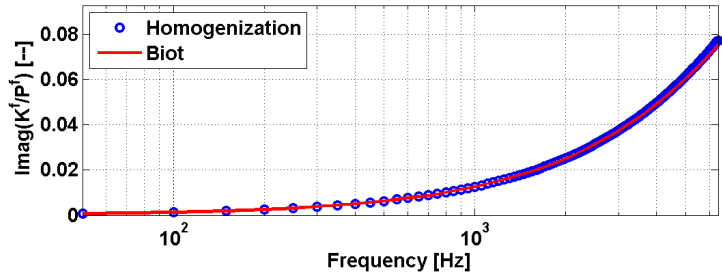

(b) Equivalent bulk modulus

Fig. 5 Comparisons of (a) equivalent density normalized by mass density of air and (b) equivalent bulk modulus normalized by static pressure of air. Blue dots are obtained by homogenization method and red lines are obtained by Biot's model with identified parameters. Red lines agree well with blue dots in frequency range of interest.

よび均質化法により得られた空気流れ抵抗 $\sigma$ を用いて Biot のモデルより求めた等価密度・等価体積弾性率の比較 である．図より，対象周波数範囲で両者は良く一致していることが分かる.

次に, トーチューシティ $\alpha_{\infty}$, 空気流れ抵抗 $\sigma$, 粘性特性長 $\Lambda$ および熱的特性長 $\Lambda^{\prime}$ にいて, $d_{f}$ のべき乗 と $(1-\phi)$ のべき乗からなる関数を仮定し，それらの指数と係数の值を最小二乗法により同定した. その結果, 各 Biot パラメータと微視的パラメータについて以下の関係式を得ることができた。

$$
\begin{aligned}
\alpha_{\infty} & =2.03-1.03 \phi[-] \\
\sigma & =3.33 \times 10^{5} d_{f}^{-2.00}(1-\phi)^{0.16}\left[\mathrm{kNs} / \mathrm{m}^{4}\right] \\
\Lambda & =0.70 d_{f}(1-\phi)^{-0.15}[\mu \mathrm{m}] \\
\Lambda^{\prime} & =0.76 d_{f}(1-\phi)^{-0.13}[\mu \mathrm{m}]
\end{aligned}
$$

ここで, $d_{f}$ は $[\mu \mathrm{m}]$ の単位における值を用いるものとする。これより， $\sigma$ は $d_{f}$ の 2 乗に反比例， $\Lambda$ と $\Lambda^{\prime}$ は $d_{f}$ に 比例することが分かる. 図 6 において，マーカーは均質化法による計算結果より同定した Biot パラメータの值， 実線は式 (39) から式 (42) の関数による值を示しており，(a) はトーチュオシティ，(b) は空気流れ抵抗，(c) は粘性 特性長，および (d) は熱的特性長である。図より，いずれの Biot パラメータにおいても両者は良く一致している ことが分かる.

\section{$5 \cdot 2$ 微視構造の寸法最適化}

ここでは, 微視構造の寸法パラメータである繊維径 $d$ および 緘維間距離 $d_{f}$ および 繊維材料の質量密度 $\rho^{s}$ を 設計変数とし，指定周波数における垂直入射吸音率の最大化を目的に，遺伝的アルゴリズムを用いて最適化する. ここでは周波数として $250 \mathrm{~Hz}, 500 \mathrm{~Hz}, 1.0 \mathrm{kHz}, 2.0 \mathrm{kHz}$ および $4.0 \mathrm{kHz}$ の 5 ケースを考え，設計変数の上下限は， 現実的な材料構成を考慮して, $0.5 \mu \mathrm{m} \leq d \leq 100 \mu \mathrm{m}, 0.800 \leq \phi \leq 0.990,900 \mathrm{~kg} / \mathrm{m}^{3} \leq \rho^{s} \leq 2000 \mathrm{~kg} / \mathrm{m}^{3}$ とする. ま た, 吸音材の厚さは $20 \mathrm{~mm}$ とした。 なお，垂直入射吸音率は伝達マトリックス法により求めており，遺伝的アル ゴリズムは Matlab の組込関数を用いている.

表 2 は，指定周波数において垂直入射吸音率が最大となる設計変数の值を示している．緎維径は $4.0 \mathrm{kHz}$ の場合 を除き $3 \mu \mathrm{m}$ から $5 \mu \mathrm{m}$ が最適值となっている. また，低周波数ほど空孔率が小さく圧縮度合いの大きい繊維材と なっており,これまで得られている経験則にも合致している. 


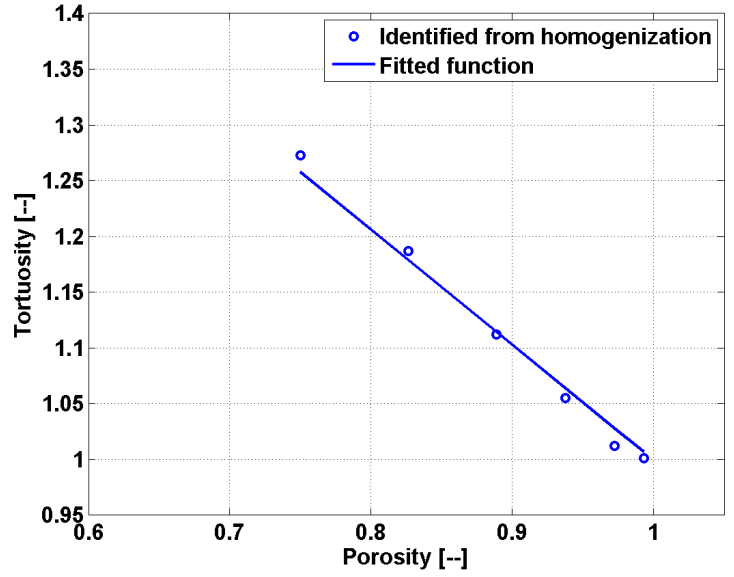

(a) Tortuosity

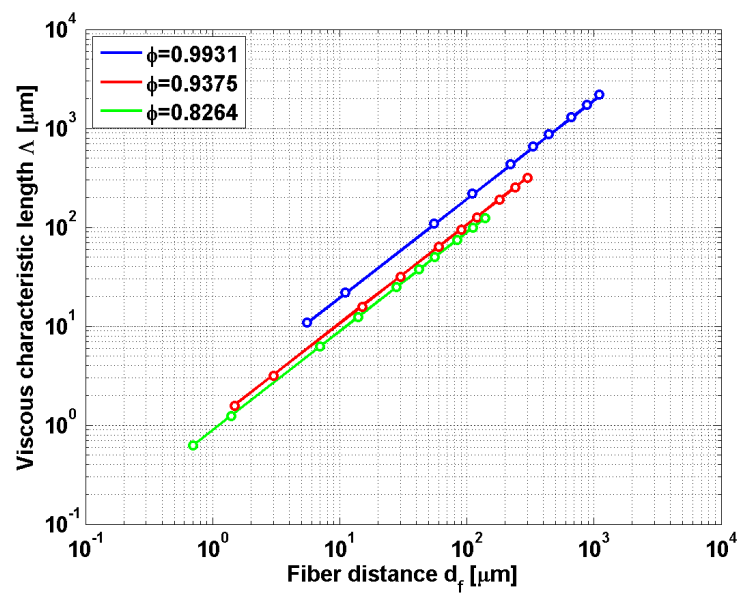

(c) Viscous characteristic length

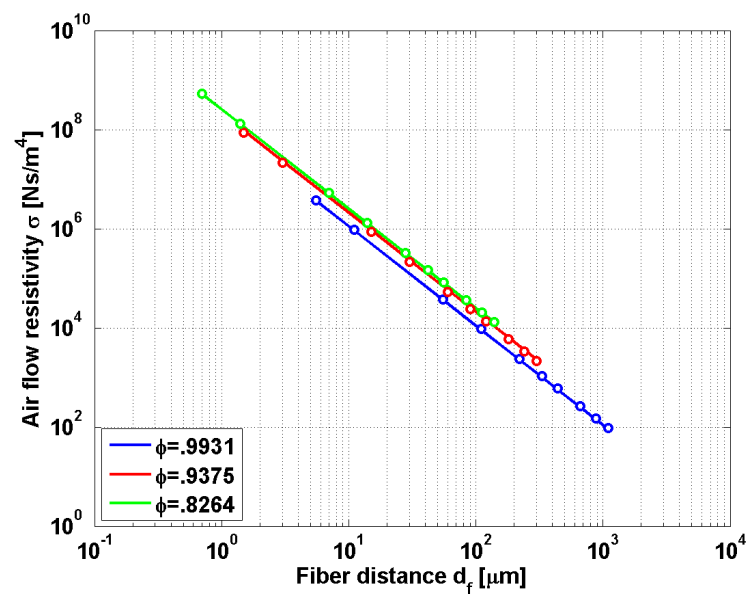

(b) Air flow resistivity

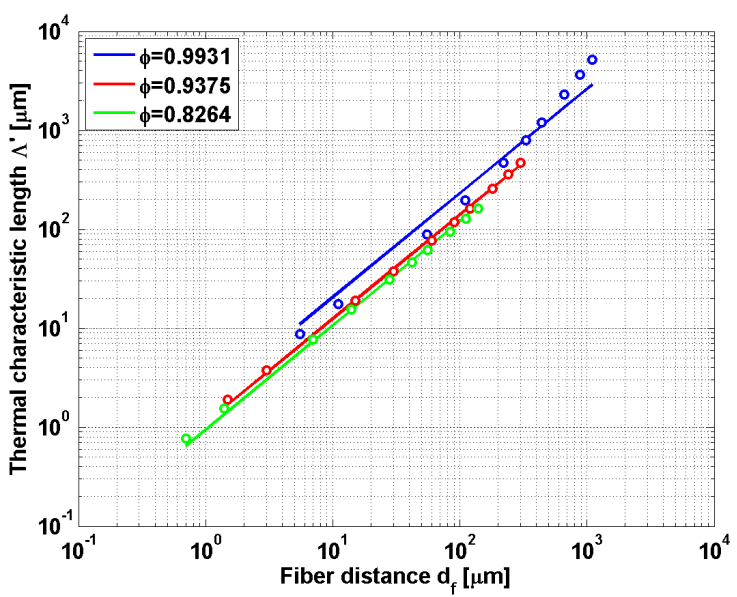

(d) Thermal characteristic length

Fig. 6 Relationships between Biot parameters and micro structural parameters. Markers represent Biot's parameters identified from the results by the homogenization method. whereas solid lines represent the functions that relate microscopic parameters and Biot's parameters: (a) tortuosity, (b) air flow resistivity, (c) viscous characteristic length and (d) thermal characteristic length.

図 7 は，指定周波数において垂直入射吸音率が最大となるように最適化したときの垂直入射吸音率を示してい る. なお, 図中の縦点線は最適化の対象とする指定周波数を示している. 指定周波数において吸音率はほぼ 1 と なっていることが分かる。

\section{6. 発泡材料の微視構造最適化}

\section{$6 \cdot 1$ 微視構造モデル}

図 8 は代表的な発泡材料であるポリウレタンフォームを走査型電子顕微鏡により撮像したものである．吸音材と して使用される場合，吸音性能を高めるため連続気泡になっていることが多い。こうした材料の微視構造を表現す るものとして, 図 9(a) に示す Kelvin セルモデルが使われている. 図 9(b) は Kelvin セルモデルのユニットセルで, 四角形と六角形を組み合わせた構造となっている. ユニットセルの 3 辺の長さが同じ場合 $\left(w_{x}=w_{y}=w_{z}=w_{f}\right)$, 四角形および六角形の空孔の大きさはそれぞれおよそ $1 / 3 w_{f}$ および $2 / 3 w_{f}$ である. 
Table 2 Optimal microscopic parameters obtained by a genetic algorithm (GA) of Matlab. The objective is to maximize absorption coefficient for normal incidence at prescribed target frequency.

\begin{tabular}{ccccc}
\hline Target frequency & $d[\mu \mathrm{m}]$ & $d_{f}[\mu \mathrm{m}]$ & $\phi[-]$ & $\rho^{s}\left[\mathrm{~kg} / \mathrm{m}^{3}\right]$ \\
\hline \hline $250 \mathrm{~Hz}$ & 4.572 & 6.452 & 0.828 & 1650. \\
$500 \mathrm{~Hz}$ & 4.956 & 14.049 & 0.932 & 956.6 \\
$1.0 \mathrm{kHz}$ & 3.278 & 25.472 & 0.987 & 1301. \\
$2.0 \mathrm{kHz}$ & 3.535 & 42.102 & 0.994 & 944.5 \\
$4.0 \mathrm{kHz}$ & 34.911 & 77.764 & 0.904 & 2000. \\
\hline
\end{tabular}

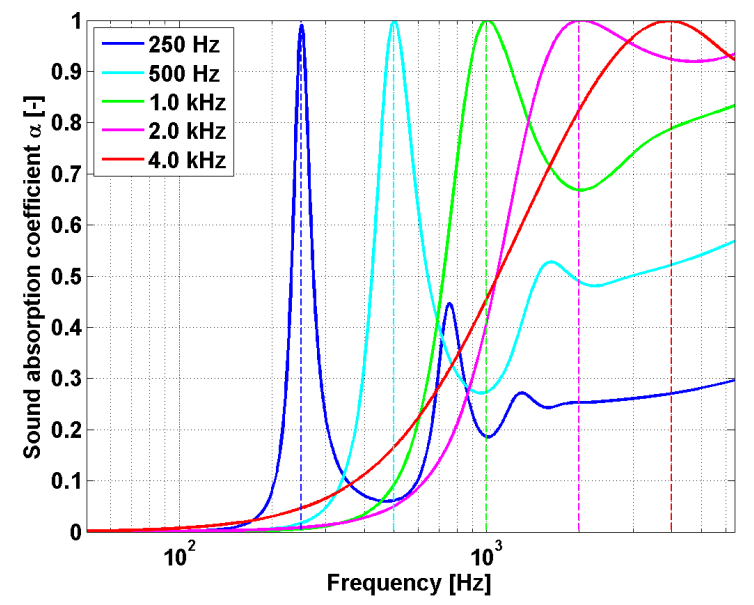

Fig. 7 Frequency characteristics of sound absorption coefficients for normal incidence when the optimal microscopic parameters for prescribed target frequency are applied. Sound absorption coefficient reaches 1.0 at the target frequency that is represented by dotted line.

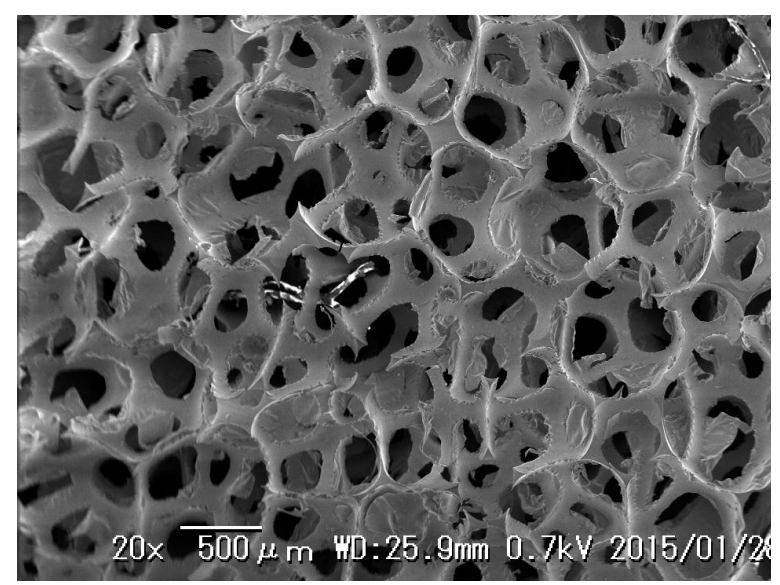

Fig. 8 Typical microscopic structure of foamed poroelastic material obtained by scanning electron microscope(SEM). Microscopic pores are connected throughout material.

\subsection{Biot パラメータと微視的パラメータの関係式}

固体相のマクロ特性であるヤング率とポアソン比，流体相のマクロ特性である空気流れ抵抗については，構造を 単純化したりすることで解析的に表現することも検討されている (Tarnow, 1997). 工学的な定義が明確でないトー 


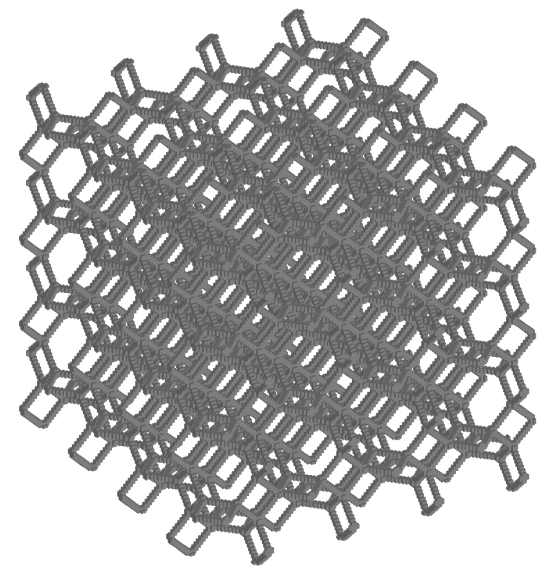

(a)

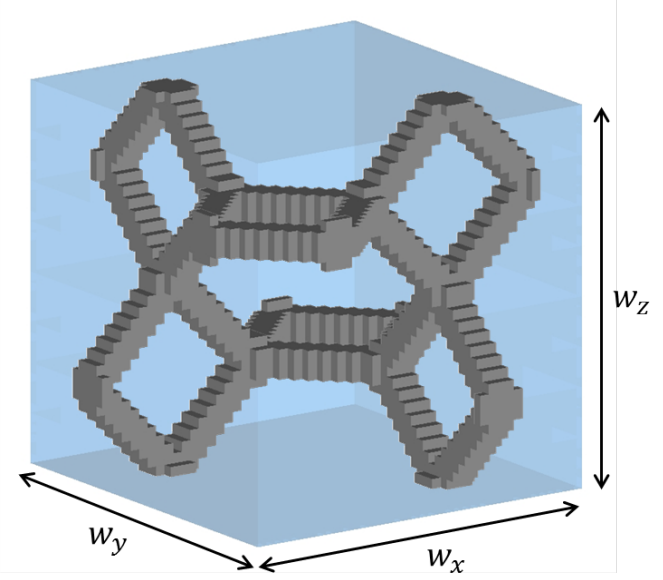

(b)

Fig. 9 (a) Kelvin cell model that represents microscopic structure of foamed poroelatic material. (b) Unit cell model of Kelvin cell. Cell sizes $w_{x}, w_{y}$ and $w_{z}$ are assumed to be equal for this study.

チュオシティや粘性特性長については, 微視構造の寸法との関係式を実験的に検討している事例もある (Boutin and Geindreau, 2008). いずれの検討事例においても，同一のモデルあるいは仮定に基づいて，全ての Biotパラメータ を同定している事例はない。ここでは，提案する手法を Kelvin セルモデルに適用し，前節と同じ方法で，均質化 法の計算結果から全ての Biotパラメータを同定する.

ユニットセルの 3 辺の長さが同じでいずれも $w_{f}$ であるとし，ユニットセルサイズ $w_{f}$ と空孔率 $\phi$ を微視構造の パラメータにとる.ここでは，ユニットセルサイズ $w_{f}$ を $1.0 \mu \mathrm{m}, 5.0 \mu \mathrm{m}, 10 \mu \mathrm{m}, 20 \mu \mathrm{m}, 40 \mu \mathrm{m}, 100 \mu \mathrm{m}, 200 \mu \mathrm{m}$, $300 \mu \mathrm{m}, 400 \mu \mathrm{m}, 1000 \mu \mathrm{m}$ の 10 種, 空孔率 $\phi$ を 0.9047, 0.9326, 0.9528, 0.9685, 0.9915の 5 種の組み合わせをと り, 合計 50 種類の微視構造を作成し, 均質化法による計算結果から Biot パラメータの值を求めた。 また, トー チューシティ $\alpha_{\infty}$, 空気流れ抵抗 $\sigma$, 粘性特性長 $\Lambda$ および熱的特性長 $\Lambda^{\prime}$ について, $w_{f}$ のべき乗 と $(1-\phi)$ のべき 乗からなる関数を仮定し, それらの指数と係数の值を最小二乗法により同定した. その結果, 各 Biotパラメータ と微視的パラメータについて以下の関係式を得ることができた.

$$
\begin{aligned}
\alpha_{\infty} & =1.43-0.43 \phi[-] \\
\sigma & =3.88 \times 10^{6} w_{f}^{-2.00}(1-\phi)^{0.355}\left[\mathrm{kNs} / \mathrm{m}^{4}\right] \\
\Lambda & =0.094 w_{f}(1-\phi)^{-0.359}[\mu \mathrm{m}] \\
\Lambda^{\prime} & =0.383 w_{f}(1-\phi)^{-0.149}[\mu \mathrm{m}]
\end{aligned}
$$

ここで, $w_{f}$ は $[\mu \mathrm{m}]$ の単位における值を用いるものとする. これより， $\sigma$ は $w_{f}$ の 2 乗に反比例， $\Lambda$ と $\Lambda^{\prime}$ は $w_{f}$ に比 例することが分かる. なお， ヤング率 $E$ とポアソン比 $v$ については Warren and Kraynik の式 (Warren and Kraynik, 1988) を用いて表すことができ，以下のように書くことができる.

$$
\begin{aligned}
& E=\frac{2(1-\phi)^{2}}{3(1.9-0.9 \phi)} E^{s} \\
& v=\frac{\phi}{2(2-\phi)}
\end{aligned}
$$

なお， $E^{s}$ は固体相を構成する材料のヤング率である.

\section{$6 \cdot 3$ 微視構造の寸法最適化}

微視構造のパラメータであるユニットセルサイズ $w_{f}$, 空孔率 $\phi$, 固体相を構成する材料のヤング率 $E^{s}$, 質量密 度 $\rho^{s}$, 損失係数 $\eta^{s}$ を設計変数とし, 指定周波数における垂直入射吸音率の最大化を目的に遺伝的アルゴリズム 
を用いて最適化する。ここでは，2つの周波数における垂直入射吸音率の平均值を最大化することを考える．周波 数は, $500 \mathrm{~Hz}$ と $1.0 \mathrm{kHz}, 500 \mathrm{~Hz}$ と $2.0 \mathrm{k} \mathrm{Hz}, 500 \mathrm{~Hz}$ と $4.0 \mathrm{kHz}, 1.0 \mathrm{kHz}$ と $2.0 \mathrm{kHz}$, および $1.0 \mathrm{kHz}$ と $4.0 \mathrm{kHz}$ の 5 ケースとし, 設計変数の上下限は, 現実的な材料構成を考慮して, $1.0 \mu \mathrm{m} \leq w_{f} \leq 500 \mu \mathrm{m}, 0.900 \leq \phi \leq 0.990$, $200 \mathrm{MPa} \leq E^{s} \leq 500 \mathrm{MPa}, 1000 \mathrm{~kg} / \mathrm{m}^{3} \leq \rho^{s} \leq 2000 \mathrm{~kg} / \mathrm{m}^{3}, 0.010 \leq \eta^{s} \leq 0.300$ とする.また，吸音材の厚さは 20 $\mathrm{mm}$ とした.

Table 3 Optimal microscopic parameters obtained by a genetic algorithm (GA) of Matlab. The objective is to maximize mean absorption coefficient for normal incidence at prescribed two target frequencies.

\begin{tabular}{cccccc}
\hline Target frequencies & $w_{f}[\mu \mathrm{m}]$ & $\phi[-]$ & $E^{s}[\mathrm{MPa}]$ & $\rho^{s}\left[\mathrm{~kg} / \mathrm{m}^{3}\right]$ & $\eta^{s}[-]$ \\
\hline \hline $500 \mathrm{~Hz}, 1.0 \mathrm{kHz}$ & 62.1 & 0.974 & 500. & 1832. & 0.297 \\
$500 \mathrm{~Hz}, 2.0 \mathrm{kHz}$ & 69.4 & 0.969 & 500. & 1959. & 0.300 \\
$500 \mathrm{~Hz}, 4.0 \mathrm{kHz}$ & 51.6 & 0.964 & 349. & 1843. & 0.011 \\
$1.0 \mathrm{kHz} .2 .0 \mathrm{kHz}$ & 75.1 & 0.989 & 500. & 1174. & 0.297 \\
$1.0 \mathrm{kHz}, 4.0 \mathrm{kHz}$ & 66.8 & 0.986 & 221. & 1262. & 0.013 \\
\hline
\end{tabular}

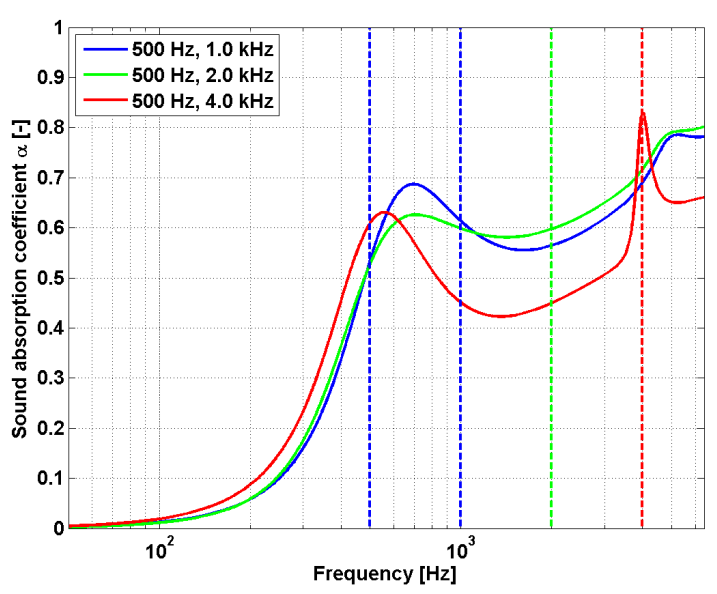

(a)

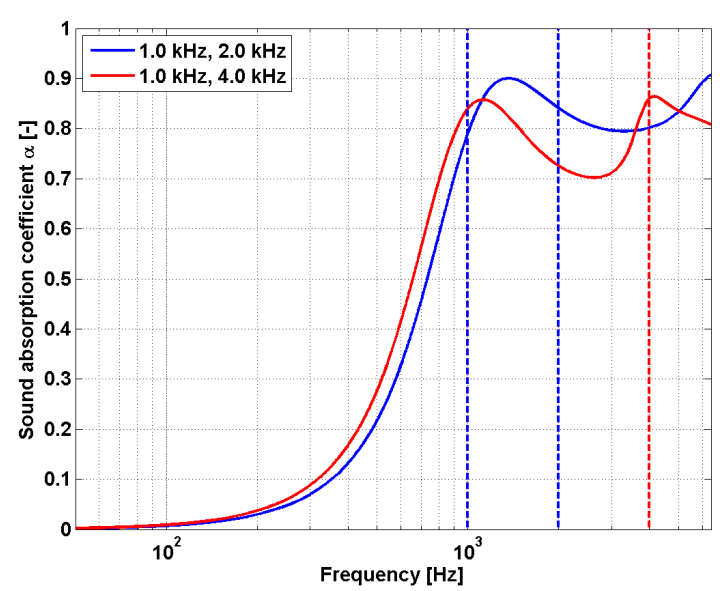

(b)

Fig. 10 Frequency characteristics of sound absorption coefficients for normal incidence when the optimal microscopic parameters for prescribed target frequency are applied: (a) target frequencies are set to 500 $\mathrm{Hz}$ and $1 \mathrm{kHz}$ (blue line), $500 \mathrm{~Hz}$ and $2.0 \mathrm{kHz}$ (green line), and $500 \mathrm{~Hz}$ and $4.0 \mathrm{kHz}$ (red line), (b) target frequencies are set to $1.0 \mathrm{kHz}$ and $2.0 \mathrm{kHz}$ (blue line), and $1.0 \mathrm{kHz}$ and $4.0 \mathrm{kHz}$ (red line).

表 3 は，各ケースにおける設計変数の最適值を示している．また，図 10 は，設計変数の最適值を用いたときの 垂直入射吸音率を示している。 なお，図中の縦点線は最適化の対象とする指定周波数を示している。図から，指 定周波数が $500 \mathrm{~Hz}$ と $4.0 \mathrm{kHz}, 1.0 \mathrm{kHz}$ と $4.0 \mathrm{kHz}$ のケースでは 2 つの指定周波数において吸音率の周波数特性が ピークになっている。また，指定周波数が $500 \mathrm{~Hz}$ と $1.0 \mathrm{kHz}, 500 \mathrm{~Hz}$ と $2.0 \mathrm{kHz}$ および $1.0 \mathrm{kHz} 2.0 \mathrm{kHz}$ のケー スでは，指定周波数において周波数特性がピークにはなっていないが，近傍の周波数域において吸音率を大きく することができている. 


\section{7. ま と}

本研究では, 多孔質吸音材の微視構造を直接扱うことのできる均質化法と, 吸音率を効率良く予測できる Biot のモデルを併用し，多孔質吸音材の微視構造の寸法を最適化するハイブリッド手法を構築した。繊維材料につい ては Limp フレームモデルにならい, 非接触直交ファイバーモデルでモデル化し，均質化法を適用して得られた計 算結果から Biot パラメータを同定し, 繊維径や繊維間距離の微視パラメータと Biot パラメータを関係付ける式を 最小二乗法により同定した。 また，発泡材料については，Kelvin セルモデルでモデル化し，ユニットセルサイズ や空孔率の微視パラメータとBiotパラメータを関係付ける式を最小二乗法により同定した. さらに, その関係式 に遺伝的アルゴリズムを用いて, 指定周波数において垂直入射吸音率を最大にする最適な微視構造パラメータを 得ることができた。

謝 辞

本研究の一部は JSPS 科研費 $17 \mathrm{~K} 06238$ および工学院大学総合研究所プロジェクト研究の助成を受けたものです.

\section{References}

Allard, J. F. and Atalla, N., Propagation of Sound in Porous Media, Wiley (2009), pp.111-135.

Atalla, N., Panneton, R. and Debergue, P., A mixed displacement-pressure formulation for poroelastic materials, Journal of Acoustical Society of America, Vol. 104, No.3 (1998), pp.1444-1452.

Auriault, J. L., Borne, L. and Chambon, R., Dynamics of porous saturated media, checking of the generalized law of Darcy, Journal of Acoustical Society of America, Vol. 77, No. 5 (1985), pp.1641-1650.

Biot, M. A., Theory of propagation of elastic waves in a fluid-saturated porous solid. I. Low-frequency range, Journal of Acoustical Society of America, Vol. 28, No. 2 (1956a), pp.168-178.

Biot, M. A., Theory of propagation of elastic waves in a fluid-saturated porous solid. II. Higher frequency range, Journal of Acoustical Society of America, Vol. 28, No. 2 (1956b), pp.179-191.

Boutin, C. and Geindreau, C., Estimates and bounds of dynamic permeability of granular media, Journal of the Acoustical Society of America, Vol. 124, No.4 (2008), pp.3576-3593.

Boutin, C., Royer, P. and Auriault, J. L., Acoustic absorption of porous surfacing with dual porosity, International Journal of Solids and Structures, Vol. 35, Issues 34-35 (1998), pp.4709-4737.

Burridge, R. and Keller, J. B., Poroelasticity equations derived fron microstructure, Journal of Acoustical Society of America, Vol. 70, No.4 (1981), pp.1140-1146.

Clopeau, T., Ferrín, J. L., Gilbert, R. P. and Mikelić, A., Homogenizing the acoustic properties of the seabed: Part II, Mathematical and Computer Modelling, Vol. 33, Issues 8-9 (2001), pp.821-841.

Delany, M. E. and Bazley, E. N., Acoustical properties of fibrous absorbent materials, Applied Acoustics, Vol. 3 , Issue 2 (1970), pp.105-116.

Gilbert, R. P. and Mikelić, A., Homogenizing the acoustic properties of the seabed: Part I, Nonlinear Analysis, Vol. 40 (2000), pp.185-212.

Levy, T., Propagation of waves in a fluid-saturated porous elastic solid, International Journal of Engineering Science, Vol. 17, Issue 9 (1979), pp.1005-1014.

Sanchez-Palencia, E., Non-Homogeneous Media and Vibration Theory, Lecture Notes in Physics, Vol. 127, SpringerVerlag (1980).

Tarnow, V., Calculation of the dynamic air flow resistivity of fiber materials, The Journal of the Acoustical Society of America, Vol. 102, Issue 3 (1997), pp.1680-1688.

Terada, K., Ito, T. and Kikuchi, N., Characterization of the mechanical behaviours of solid-fluid mixture by the homogenization method, Computer Methods in Applied Mechanics and Engineering, Vol. 153, Issues 3-4 (1998), pp.223-257. 
Warren, W. E. and Kraynik, A. M., The linear elastic properties of open-cell foams, Journal of Applied Mechanics, Vol. 55, No.2 (1988), pp.341-346.

Yamamoto, T., Maruyama, S., Terada, K., Izui, K. and Nishiwaki, S., A generalized macroscopic model for soundabsorbing poroelastic media using a homogenization method, Computer Methods in Applied Mechanics and Engineering, Vol. 200, No.1 (2011), pp.251-264.

\section{付録: 複素関数に拡張した Levenberg-Marquardt 法}

実数関数に対する非線形最小二乗法である Levenberg-Marquardt 法を複素関数に拡張する.すなわち，複素残差 $r_{i}(i=1,2, \cdots m)$ の絶対值二乗和 $S=\sum_{i=1}^{m} r_{i} r_{i}^{*}$ を実数関数の場合と同様のアルゴリズムで最小化する. なお，*は 複素共役を表すものとする.

データ $\left(x_{i}, y_{i}\right)$ と係数 $\beta_{j}$ を有する関数 $f\left(x, \beta_{j}\right)(j=1,2, \cdots n)$ の残差二乗和 $S$ は以下のように書くことができる.

$$
S\left(x_{i}, y_{i}, \beta_{j}\right)=\sum_{i=1}^{m} r_{i} r_{i}^{*}=\sum_{i=1}^{m}\left[y_{i}-f\left(x_{i}, \beta_{j}\right)\right]\left[y_{i}-f\left(x_{i}, \beta_{j}\right)\right]^{*}
$$

係数 $\beta_{j}$ による偏微分は

$$
\frac{\partial S}{\partial \beta_{j}}=\sum_{i=1}^{m} r_{i} \frac{\partial r_{i}^{*}}{\partial \beta_{j}}+\frac{\partial r_{i}}{\partial \beta_{j}} r_{i}^{*}=-\sum_{i=1}^{m}\left(y_{i}-f\left(x_{i}, \beta_{j}\right)\right) \frac{\partial f\left(x_{i}, \beta_{j}\right)^{*}}{\partial \beta_{j}}+\frac{\partial f\left(x_{i}, \beta_{j}\right)}{\partial \beta_{j}}\left(y_{i}-f\left(x_{i}, \beta_{j}\right)\right)^{*}
$$

$\Delta \beta_{j}=\beta_{j}-\beta_{j}^{(k)}$ として，すなわち $\beta_{j}=\beta_{j}^{(k)}+\Delta \beta_{j}$ として, $f\left(x_{i}, \beta_{j}\right)$ を $\beta_{j}^{(k)}$ のまわりで展開し, 1 次式で近似する と以下のように書くことができる.

$$
\begin{aligned}
& f\left(x_{i}, \beta_{j}\right)=f\left(x_{i}, \beta_{j}^{(k)}\right)+\sum_{j=1}^{n} \frac{\partial f\left(x_{i}, \beta_{j}\right)}{\partial \beta_{j}}\left(\beta_{j}-\beta_{j}^{(k)}\right)+\cdots \approx f\left(x_{i}, \beta_{j}^{(k)}\right)+\sum_{j=1}^{n} J_{i j} \Delta \beta_{j} \\
& \text { ここで, } \frac{\partial f\left(x_{i}, \beta_{j}\right)}{\partial \beta_{j}}=J_{i j} \text { である. } \Delta y_{i}=y_{i}-f\left(x_{i}, \beta_{j}^{(k)}\right) \text { として } \\
& \frac{\partial S}{\partial \beta_{j}}=-\sum_{i=1}^{m}\left[\left(y_{i}-f\left(x_{i}, \beta_{j}\right)\right) J_{i j}^{*}+\left(y_{i}-f\left(x_{i}, \beta_{j}\right)\right)^{*} J_{i j}\right]=\sum_{i=1}^{m} \sum_{l=1}^{n}\left(J_{i j}^{*} J_{i l}+J_{i j} J_{i l}^{*}\right) \Delta \beta_{l}-\sum_{i=1}^{m}\left(J_{i j}^{*} \Delta y_{i}+J_{i j} \Delta y_{i}^{*}\right)
\end{aligned}
$$

$S$ が最小のとき $\frac{\partial S}{\partial \beta_{j}}=0$ となることから，

$$
\sum_{i=1}^{m} \sum_{l=1}^{n}\left(J_{i j}^{*} J_{i l}+J_{i j} J_{i l}^{*}\right) \Delta \beta_{l}=\sum_{i=1}^{m}\left(J_{i j}^{*} \Delta y_{i}+J_{i j} \Delta y_{i}^{*}\right), \quad j=1 \cdots n
$$

これは $n \times n$ の方程式になり，マトリックスで表記すると次式で表すことができる.

$$
\left(\boldsymbol{J}^{* T} \boldsymbol{J}+\boldsymbol{J}^{T} \boldsymbol{J}^{*}\right) \boldsymbol{\Delta} \boldsymbol{\beta}=\boldsymbol{J}^{* T} \boldsymbol{\Delta} \boldsymbol{y}+\boldsymbol{J}^{T} \boldsymbol{\Delta} \boldsymbol{y}^{*}
$$

なお，安定性のため実数関数の場合と同様に次式を用いる.

$$
\left(\boldsymbol{J}^{* T} \boldsymbol{J}+\boldsymbol{J}^{T} \boldsymbol{J}^{*}+\lambda \operatorname{diag}\left(\boldsymbol{J}^{* T} \boldsymbol{J}+\boldsymbol{J}^{T} \boldsymbol{J}^{*}\right)\right) \boldsymbol{\Delta} \boldsymbol{\beta}=\boldsymbol{J}^{* T} \boldsymbol{\Delta} \boldsymbol{y}+\boldsymbol{J}^{T} \boldsymbol{\Delta} \boldsymbol{y}^{*}, \quad \lambda \geq 0
$$

得られた解より $\boldsymbol{\beta}^{(k)}$ を $\boldsymbol{\beta}^{(k+1)}=\boldsymbol{\beta}^{(k)}+\Delta \boldsymbol{\beta}$ で更新し, 上記のプロセスを $S$ が所定の閾值より小さくなるまで繰り 返す. 